\title{
Microsoft's Monopoly: Anti-Competitive Behavior, Predatory Tactics, And The Failure Of Governmental Will
}

Gregory T. Jenkins, (E-mail: gtjenkins@techemail.com), William Paterson University Robert W. Bing, (E-mail: BingR@wpunj.edu), William Paterson University

\begin{abstract}
Thirty years ago, Microsoft Corp. was founded by Bill Gates and Paul Allen. To understand how the company has gained competitive advantage we examine how the company used unfair, anticompetitive, and predatory approaches in their business. We discuss how we have come to the belief that the government settlement in United States and State of New York, et al., v. Microsoft Corporation imposing restrictions on Microsoft's behavior and monitoring its actions for compliance is not enough to keep it from abusing its monopolistic power and does too little to prevent it from dominating the software and operating system industry today.
\end{abstract}

\section{INTRODUCTION}

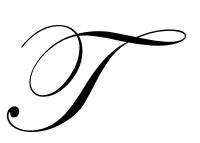

hirty years ago, in November 1975, Microsoft Corp. was founded by Bill Gates and Paul Allen. Today the company has grown to 60,000 employees in over 90 countries. The company's stock is traded on the NASDAQ exchange and the company has global sales in the tens of billions of dollars.

Microsoft is known for its software applications, hardware devices, its MSNBC cable television network, the MSN web portal, and even home entertainment products such as WebTV and Xbox. But most of all Microsoft is known for its Windows operating system and its office productivity suite which contains Word, Excel, PowerPoint, Outlook, Photo Editor, and Publisher. To truly understand how the company has gained competitive advantage we should look at how they use unfair, anti-competitive, and predatory approaches in their business.

It all began in 1981 when Microsoft, still a young company, was awarded a contract by IBM to write an operating system for its personal computers (PC). Microsoft had no operating system at that time, but it purchased one, made some changes, and the result was MS-DOS (Microsoft Disk Operating System). As part of its contract with IBM, Microsoft was allowed to license MS-DOS to other companies. The company quickly used this position and aggressively marketed the system to manufacturers of IBM PC clones, such as Compaq. Microsoft's dominance began as it quickly went from a small player to the predominant software vendor (Microsoft, 2005).

In early 1990 the company was so successful that it held $90 \%$ of the market share (Khan et al, 2004). One may ask how did a company with so many competitors (such as Netscape, Novell, Sun Microsystems, and IBM) gain so much of the market. The United States Department of Justice and the Federal Trade Commission were also asking the same. In the early months of 1990 the Federal Trade Commission began questioning Microsoft's business practices and launched an investigation into the possibility that Microsoft violated antitrust acts which are designed to prevent companies from becoming a monopoly.

Microsoft introduced the Windows 95 operating system in 1995. It is at this time that Microsoft began bundling its Internet Explorer web browser with its Windows operating system. According to Bennett (1999), it was also at this time when the Department of Justice first accused Microsoft of using exclusionary and anticompetitive contracts with PC makers. Microsoft signed a consent decree in which it agreed to accept certain restrictions on its licensing agreements. The Department of Justice was monitoring Microsoft's actions and it came to believe that 
Microsoft violated the decree, abused monopolistic power and gained market share by using predatory tactics against its competitors. In May of 1998, the United States Department of Justice along with twenty US states filed an antitrust lawsuit against Microsoft, United States v. Microsoft, alleging the company abused monopolistic power and had gained market share through unfair business practices.

The company was charged with violating the following anti-trust acts:

- The Sherman Act is the first measure passed by the United States Congress in 1890 to prohibit trusts. The act was named after Senator John Sherman and is based on the constitutional power of Congress to regulate interstate commerce. The statute authorizes the federal government to institute proceedings against trusts with the intention of dissolving them (Columbia Electronic Encyclopedia, 2005). The statute has as its premise that the nation is harmed if rival businesses agree to bring their market power together or in the alternative act to limit competition. It also prohibits certain practices such as predatory pricing (which is the sale of products below cost in order to eliminate competition.)

- $\quad$ The Clayton Act of 1914 supplements the Sherman Act and was created to remedy perceived deficiencies in the Sherman Act. It deals with specific anticompetitive activities which substantially reduce competition or create monopolistic power. One prohibited practice under the act is a tying arrangement where a seller of a product uses its market power over one product to require a buyer to purchase a second product.

Both the Sherman Act and Clayton Act are enforced by the Federal Trade Commission and the Antitrust Division of the United States Department of Justice (Clayton Antitrust Act, 2005).

According to Stein (1999), there were four main arguments raised by the prosecution in the United States $v$. Microsoft: (i) the main argument is that Microsoft unlawfully maintained a monopoly in operating systems for personal computers; (ii) the second argument is that Microsoft violated Section One of the Sherman Act by unlawfully tying its Internet Explorer web browser to its Windows operating system; (iii) the third claim, also under Section One of the Sherman Act, is that Microsoft entered into numerous unlawful exclusionary agreements; and (iv) the Department of Justice claims that Microsoft attempted to monopolize the browser market using anticompetitive and predatory practices.

During the trial the Department of Justice entered items into evidence that Microsoft did not object to; but Microsoft's defense was always about innovation, stating that as a technology company it has a right to innovation and fair competition.

After reading the brief of United States and State of New York, et al., v. Microsoft Corporation, we believe and agree with both the prosecution and the courts that there is substantial evidence that demonstrates Microsoft used a broad range of ways in which it maintained its monopoly and tried to eliminate competitive technologies.

In reading the evidence presented by the Department of Justice and Microsoft's response, two types of behavior stand out; predatory conduct and exclusionary behavior.

\section{PREDATORY CONDUCT}

Under predatory conduct several allegations were made against Microsoft, with two tactics that are notable:

- $\quad$ The tying and bundling of Internet Explorer with Windows operating system: When Windows 95 was launched, Microsoft bundled its Internet Explorer with the operating system. This is a clear example of both predatory pricing where a company undercharges for its products for the sole purpose of forcing its competitors out of business and a tying arrangement. Microsoft claimed that this bundling of the two products was a result of innovation and that both items were part of an integrated system. We disagree and believe that these two components are separate products. Any customer that purchased a Windows operating system or a computer with a Windows operating system pre-installed was not given a choice as to the type of 
Internet browser they could use. Microsoft also claimed that since the two were the same product users would get Internet Explorer for free. To us this is a clear indication that Microsoft was using its market power in the operating system market to gain market share in the web browser market. Microsoft was already known for its operating system and had sold millions of copies. The number of users on the Internet and World Wide Web was beginning to increase dramatically in the mid-1990s and Microsoft took advantage of the fact that it could reach all of its operating system users and give them Internet Explorer. Also, by giving away their Internet Explorer browser for free the company was keeping other browsers such as Netscape and America Online (AOL) from becoming a competitive force.

- Java programming language: Java is a platform independent programming language that allows program applications to run in web browsers. The Department of Justice alleged that Microsoft tried to develop its own version of Java so that the Java language would not become standardized and therefore used by all web browsers. By eliminating Java as competition, Microsoft would be sacrificing browser profits in the short run (by giving Internet Explorer away for free) but they would be preserving operating system profits in the long run.

\section{EXCLUSIONARY BEHAVIOR}

In addition to the tying arrangement and predatory pricing Microsoft would only sign agreements with Original Engineering Manufacturers (OEM), such as Dell and Compaq, if they agreed not to remove Internet Explorer from the desktop or feature another web browser. We see this as a clear attempt by Microsoft to exclude their competitors from creating business relationships with computer manufacturers and to prevent users having a choice of Internet browsers. In furtherance of this goal the corporation engaged in several activities. It offered rebates to vendors if they agreed not to promote competing operating systems. The company also showed preferential treatment to mobile phone and PDA vendors if they featured Internet Explorer as their choice of web browser for such services such as shopping, web surfing, chatting and playing games. In addition, Microsoft required vendors who wanted to purchase Windows operating system for a certain class of computers, for example laptops, to purchase the operating system for every computer the vendor sold, i.e. desktop computers and PDA devices.

After reading the arguments against Microsoft and its defense, we believe that a clear pattern emerges. Microsoft's responses to the government's complaints are weak and provide no real solid evidence or support as to the reasoning for its actions. If anything, this evidence ended up hurting its case. For example, Microsoft claimed that the Windows operating system was hindered by the removal of Internet Explorer. When the judge ordered evidence, Microsoft submitted a videotape demonstration supposedly showing how removing Internet Explorer from Windows caused slowdowns. However, during cross-examination the plaintiff noticed that some icons on the desktop disappeared and then reappeared, which the government argued that Microsoft might have falsified the videotape evidence causing Microsoft to lose credibility. If they had truly provided evidence showing Windows would not work properly without Internet Explorer, they may have had a chance at an acquittal if the operating system had been hindered without Internet Explorer. In addition, falsifying evidence lends credibility to the argument that the company was hiding something.

The court proceedings dragged on for years. On November 5, 1999, US District Court Judge Thomas Penfield Jackson found that Microsoft indeed held a monopoly and did use it to harm consumers and other companies. Judge Jackson appointed a mediator to handle negotiations between Microsoft and the government in hopes that a settlement could be reached in the on-going antitrust case. Efforts to mediate the resolution ended on April 1, 2000 and on April 3, 2000 Judge Jackson issued a final verdict that Microsoft had violated the nation's antitrust laws by holding a monopoly and maintained its monopolistic power though anti-competitive means. As a result of the verdict, the Justice Department and a group of states' attorneys general ask Judge Jackson to split Microsoft into separate corporations. The first would be devoted to the Windows operating system and the other for software applications.

On June 7, 2000 Judge Jackson issued a two-part ruling: (i) Microsoft had committed monopolization, attempted monopolization, and violated sections 1 and 2 of the Sherman Act, and (ii) Microsoft Corp. be broken up 
into two different companies - one for its Windows operating systems and one for it software applications (United States v. Microsoft, 2005).

Microsoft appealed immediately and the U.S. Court of Appeals for the D.C. Circuit disagreed as to the browser tying arrangements; criticized Judge Jackson for his personal conduct in the case but did agree that the company had stifled competition. However, it did overturn the breakup of Microsoft. The case was remanded to the lower court for resolution.

President George W. Bush intervened and stated that it was no longer the policy of the Justice Department to break-up the corporation. The Department of Justice and Microsoft agreed to a settlement where some restrictions were imposed upon Microsoft, but it remains one company and continues to dominate the operating and software industries. The settlement was approved by U.S. District Court Judge Kollar-Kotelly. Interestingly, several of the states and the District of Columbia did not agree with the settlement. They stated that the settlement did not go far enough to curb Microsoft's anticompetitive behavior. The settlement was approved by the U.S. Court of Appeals.

In our opinion we agree with the states and the District of Columbia that the final settlement did not do much to remedy Microsoft Corp's behavior. The company paid some fines and has some restrictions placed on its business practices. We do not believe that imposing restrictions on Microsoft's practices and monitoring its actions for compliance is enough to keep it from abusing its monopolistic power and does too little to prevent it from dominating the software and operating system industry.

Others have made similar arguments. Some have even argued the opposite, including Nobel Laureate Milton Friedman; that no case should have been initiated with free market forces prevailing. According to Bennett (1999) Microsoft should have been split even further into three divisions based on its product lines: a company for Windows operating systems, a company for development tools, and a company for its office suite. Even this solution causes us to wonder what products belong in the operating system group since the company has bundled products for so long. Microsoft already has $90 \%$ market share and breaking-up the company based on product lines might well have created two or three monopolists in each product line rather than one.

It is arguable that Judge Thomas Penfield Jackson's original remedy to break-up Microsoft into two companies was a step in the right direction. It is our belief that one only has to look to the break-up of the once monopolistic AT\&T to see the possible results both in pricing and technological growth created under capitalistic competition resulting from such a break-up. In any case, as the appeals court overturned the break-up of Microsoft, the resulting settlement left the Windows monopoly intact. However, simply breaking-up the company as the sole remedy and allowing it to continue with normal business practices might not have been effective to place monopolistic controls on the company. The company did have some restrictions imposed on their business practices regarding licensing agreements with original engineering manufacturers and vendors; the altering of configuration of applications, and giving users the option to choose a different web browser other than Internet Explorer. Imposing restraints gave the Federal Trade Commission and the Department of Justice control over Microsoft's behavior. Now the company must follow strict guidelines and will be closely watched by a monitoring group appointed by the Federal Trade Commission. However, even these restrictions expire on November 12, 2007.

To summarize, Microsoft's predatory conduct and exclusionary behavior were not appropriate or even legal methods of conducting business. The main areas of fault are as follows:

- $\quad$ The bundling of Internet Explorer with Windows Operating System using the market power of its operating system to gain market share in the web browser market.

- $\quad$ Giving away its Internet Explorer web browser for free to keep other web browsers from becoming competitive and attempting to force other web browsers out of business.

- $\quad$ Creating a Microsoft-specific version of Java so that the Java language would not become standardized and therefore used by all web browsers.

- Microsoft featured Internet service providers on its Windows desktop if the provider denied the user a choice of web browsers allowing them to use only Internet Explorer. 
- $\quad$ Microsoft signed agreements with PC vendors like Dell if they agreed not to remove Internet Explorer from the desktop and agreed not to feature other browsers such as Netscape Communicator.

- $\quad$ Microsoft offered rebates to PC vendors if they agreed not to promote other operating systems.

- Microsoft gave preferential treatment to PDA and cellular phone vendors if they featured Internet Explorer as their web browser.

From a user's point-of-view, Windows operating system is very user-friendly. A bundle consisting of a Windows operating system, Internet Explorer web browser, and Microsoft's productivity office suite that is preinstalled on a computer when purchased is very accommodating. By simply turning on a computer in a matter of moments a user can be surfing the Internet or writing a letter, with no additional software packages to purchase and install. It is probable that the typical user does not care if Microsoft has a monopoly or how they have managed to capture $90 \%$ of the market share and is concerned solely with how easy it is for them to use a computer to complete their necessary tasks. However, from a societal point of view, looking at technology and market power, we support the Department of Justice and their attempt to ensure Microsoft's business practices stay within legal boundaries. Our disagreement is that it did not go far enough in resolving the predatory behavior of the company.

The company has launched a website titled the "Freedom to Innovate Network" where it provides a newsletter and legal updates on the company with Microsoft's oft-stated defense of the need as a technology company for innovation and fair competition. According to the company's website almost all of the legal issues that arose from the U.S. antitrust case have been resolved. The "Freedom to Innovate" website also discusses the U.S.-Central America-Dominican Republic Free Trade Agreement (DR-CAFTA) and urges individuals to encourage their U.S. Representative and Senators to vote for this free trade agreement. This agreement would allow Microsoft and other U.S. companies' greater access to foreign markets by reducing or eliminating tariffs and other trade barriers. Not to argue the merits of the legislation which is beyond the scope of this paper, it does seem clear that Microsoft's international influence would only increase with passage and perhaps allow it to have even greater monopolist power on a global level.

Microsoft has faced similar charges of antitrust and unfair competition in Europe and Asia. In Europe the company has appealed the ruling from the European Commission where it fined Microsoft approximately $\$ 613$ million US dollars. The appeals process could take several years. The legal situation is similar in Asia. The South Korean Fair Trade Commission has launched an investigation into allegations against Microsoft for unfair competitive practices. The Japanese Fair Trade Commission also claims Microsoft is guilty of unfair business and predatory tactics. The results of both lawsuits in Asia are pending (Microsoft, 2005).

Even though Microsoft has endured the longevity of the antitrust lawsuit and was given restrictions to abide by, it still remains dominant and to our way of thinking a monopolistic force in the operating system and software industries. We believe that the settlement in the case did not end its domination in the marketplace. The company has used its monopoly power for too long and the effects of may well be irreversible. Even after the trial and settlement with restrictions imposed on the company, Microsoft's dominance in technology has created a market where competitors and the potential for innovative technology continue to be stifled in this post $U S$ v. Microsoft world.

\section{REFERENCES}

1. Bennett, Eric (1999). U.S. v. Microsoft: Choosing the Right Remedy. Retrieved November 11, 2005 from the World Wide Web: http://www.vcnet.com/bms/features/remedies.shtml.

2. Clayton Antitrust Act (2005). Wikipedia, The Free Encyclopedia. Retrieved November 11, 2005 from the World Wide Web: http://en.wikipedia.org/w/index.php?title=Clayton_Antitrust_Act\&oldid=29730407.

3. Columbia Electronic Encyclopedia. (2005). Retrieved October 22, 2005, from the World Wide Web: http://www.encyclopedia.com/html/S/ShermanJ1.asp.

4. Khan, S., Islam, F., \& Ahmed, S. (June 2004). Is Microsoft a Monopoly: An Empirical Test. American Business Review; 22, 2, 130-134.

5. $\quad$ Legal Update (2005). Retrieved November 11, 2005 from the World Wide Web: http://www.microsoft.com/freedomtoinnovate/legalissues/default.asp. 
6. Microsoft (2005). Wikipedia, The Free Encyclopedia. Retrieved November 11, 2005 from the World Wide Web: http://en.wikipedia.org/w/index.php?title=Microsoft\&oldid=29761963.

7. Stein, Tom (1999). Microsoft Ruled a Monopoly. Court finds firm abused its power. Retrieved November 11, 2005 from the World Wide Web: http://www.sfgate.com/cgi-bin/article.cgi?file=/chronicle/archive/ 1999/11/06/MN94897.DTL.

8. United States and State of New York, et al., v. Microsoft Corporation. Retrieved November 11, 2005 from the World Wide Web: http://www.usdoj.gov/atr/cases/f7200/7230.htm.

9. United States v. Microsoft (2005). Wikipedia, The Free Encyclopedia. Retrieved November 11, 2005, from the World Wide Web: http://en.wikipedia.org/w/index.php?title=United_States_v._

Microsoft\&oldid=29709722.

\section{NOTES}

